\title{
La interdiscursividad en la configuración del personaje de Tristana (Galdós-Buñuel)
}

\section{The interdiscursivity in the configuration of the character of Tristana (Galdós-Buñuel)}

\author{
LAURA SÁNCHEZ LÓPEZ \\ (Universidad Autónoma de Madrid) \\ lausanlop@hotmail.com \\ ORCID ID: 0000-0003-2136-3612
}

\begin{abstract}
Resumen: El objetivo del presente artículo consiste en realizar un análisis interdiscursivo sobre la configuración del personaje de Tristana en la novela de Benito Pérez Galdós y en la adaptación cinematográfica de Luis Buñuel, ambas con un título homónimo al nombre del personaje principal femenino. Además, se intentará encontrar una motivación histórica, bajo una perspectiva feminista, que justifique el principal cambio que realiza el cineasta en la construcción del personaje. Para ello, será necesario introducir algunos conceptos sobre el análisis interdiscursivo, propuestos por Tomás Albaladejo, así como nociones básicas sobre la transducción, a cargo de Doležel.
\end{abstract}

Palabras clave: Galdós, Buñuel, Tristana, análisis interdiscursivo, feminismo.

\begin{abstract}
The objective of the present paper is to perform an interdiscursive analysis on the configuration of the character of Tristana in the novel by Benito Pérez Galdós and in the cinematographic adaptation of Luis Buñuel, both with a title of the same name as the main female character. In addition, we will try to find a historical motivation, under a feminist perspective, that justifies the main change that the filmmaker makes in the construction of the character. For this, it will be necessary to introduce some concepts on interdiscursive analysis, proposed by Tomás Albaladejo, as well as basic notions about transduction, by Doležel.
\end{abstract}

Keywords: Galdós, Buñuel, Tristana, interdiscursive analysis, feminism. 


\section{Laura Sánchez López}

\section{El ANÁLISIS INTERDISCURSIVO Y LA TRANSDUCCIÓN}

El análisis interdiscursivo es una herramienta crítica útil y eficaz, un «instrumental $[\ldots]$ de práctica analítica y fundamentación teórica» (Albaladejo, 2008: 257) que se encuentra en estrecha relación con la Literatura Comparada. El fin del análisis interdiscursivo es analizar los instrumentos analíticos de las distintas disciplinas «con el fin de extraer conceptos, perspectivas y estrategias que puedan ser válida para el análisis de discursos pertenecientes a clases distintas de las que habitualmente constituyen sus objetos» (2008: 259).

En la interdiscursividad aparece el contexto de ambos discursos, lo que remite a otro concepto propuesto por Albaladejo como es la Retórica cultural. De hecho, las diferencias fundamentales que presenta la protagonista de Tristana tienen un trasfondo contextual.

El análisis interdiscursivo contribuye a la Literatura Comparada porque introduce de manera explícita la comparación entre los discursos de distintas clases. Resulta una manera de aproximación muy nutritiva, sobre todo si se tiene en cuenta que el método comparativo es una fuente inagotable de conocimiento.

Un término muy relacionado con el análisis interdiscursivo es la transducción (Doležel, 1990), que supone un cambio en la concepción del sistema de la comunicación literaria y se identifica con unas «complejas cadenas de transmisión» (Doležel, 1990: 230), lo que denota la apertura y fluctuación de ese sistema. La transducción hace referencia a la creación de un texto, literario o no, a partir de otro: «el receptor del texto original articula el resultado de su procesamiento en un nuevo texto» (1990: 231).

Dentro de los fenómenos y actividades que abarca la transducción, para esta ocasión interesa la intertextualidad y la influencia, así como la transformación de un género en otro y solamente uno de los modos de transducción, la adaptación literaria, pues es el caso en donde un texto literario se transforma en otro texto (1990: 234). De esta forma, Buñuel es el receptor de la obra de Galdós que se convierte, a su vez, en el emisor del filme de Tristana.

La principal diferencia que se encuentra en ambos discursos será la trama, es decir, la forma en la que se distribuye y organiza el argumento, así como el principal problema de poner en diálogo la literatura con el cine es que habrá elementos inconmensurables o voluntariamente desechados que darán al receptor indicios para seguir la lectura que ambos artistas han decidido potenciar en sus respectivas obras.

\section{LA CONFIGURACIÓN DEL PERSONAJE: DIFERENCIAS Y SIMILITUDES}

En este apartado, el objetivo es observar las principales diferencias y similitudes que presenta la configuración del personaje protagonista. No se 
pretende, de momento, justificar los cambios que ha realizado Buñuel ni encontrar la motivación de ellos; así como tampoco explicitar los cambios estructurales de la trama ni profundizar en la relación que establece Tristana con don Lope. A sabiendas de que el final de ambas obras ha sido sobradamente reseñado, interpretado y criticado, solo se tomarán en consideración conceptos que resulten pertinentes para esclarecer aspectos relacionados con la conformación de la identidad de Tristana.

Así mismo, se omiten las nociones aportadas por Pérez Bowie a la hora de explicitar las dificultades que presenta el concepto de adaptación (el cual no sería muy preciso en este caso, prefiriéndose el de recreación, pero indistintamente utilizado), siendo de valor solo cuando cita a Cattrysse para hablar de los deslizamientos y los no-deslizamientos (Pérez Bowie, 2004: 284-285) en relación a la manera en la que se ha realizado, o no, la equivalencia entre los dos productos artísticos.

El primer punto que se debe abordar es el relativo al narrador, por ser este quien cuenta la historia y quien sugestiona al lector a la hora de formar prejuicios en torno a los personajes. Además, es el encargado de dirigir la atención del receptor en aquellos pasajes que considere relevantes. En el mundo cinematográfico, esta última función no corre obligatoriamente a cargo del narrador, sino que se trata del focalizador, pues escoge qué escenas mostrar y, por otro lado, la perspectiva desde la que lo hace.

Ambos narradores deciden quedarse a un lado $\mathrm{y}$, sin llegar a ser heterodiegéticos, se introducen en la obra de manera explícita aportando su subjetividad. Así, en Galdós aparecerá la primera persona: «tuve conocimiento de tal personaje y pude observar $[\ldots]$ dijéronme $[\ldots]$ » (Galdós, 2001:103-104); y Buñuel, coincidiendo en gran parte con el focalizador, decide enmarcar escenas que adquieren, como se verá más adelante, una significación muy precisa que influye para la interpretación de la obra.

Además, un dato curioso es que el narrador en Galdós delega la responsabilidad de la narración en los personajes, adquiriendo este un rol antitético: se presenta como un personaje secundario, perteneciente a la burguesía acomodada y defensor del orden, mientras que los deseos de revolución y las ideas liberales y progresistas aparecen en boca de sus personajes. Por ello, será tan significativa la pérdida de voz que sufre Tristana y que se referirá más adelante.

Una vez introducido este elemento, lo siguiente que se debe tratar es el proceso de transformación que sufre Tristana; para ello, se toma como referencia el texto de Cassetti sobre Cómo analizar un film. Dentro de esta cuestión, se debe definir primero la manera en la que se conforma como personaje. El principal problema es que «determinar clara y sintéticamente en qué consiste y qué es lo que en definitiva caracteriza a un "personaje" [...] resulta bastante difícil. Preferimos, por lo tanto, no buscar una 


\section{Laura Sánchez López}

respuesta unívoca y recurrir más bien a tres perspectivas posibles» (Cassetti, 1991: 177). Cassetti se refiere a abordar la configuración del personaje desde tres niveles: el fenomenológico, el formal y el abstracto, dentro de los cuales solo se rescatarán aquellas aportaciones que resulten oportunas para el análisis de Tristana.

En el primer nivel se tiene en cuenta el carácter y el comportamiento tal como se expresan (Cassetti, 1991: 183), y lo primordial será «constituir una perfecta simulación de aquello con lo que nos enfrentamos en la vida» (1991: 178). Bajo estas premisas y distinciones, se puede describir a Tristana como un personaje redondo, por tratarse de alguien complejo y variado, tanto en sus cambios de actitud como en el transcurso de sus acciones; contrastado, ya que se presenta como inestable y contradictorio, pues no hay que olvidar, sobre todo en la novela, cómo Tristana pasa de querer ser pintora, a ser música y luego actriz, además de cómo desprecia a don Lope pero a la vez lo quiere; por último, dinámico, sobre todo en el filme, por mantenerse en constante evolución (ya sea positiva o negativa), en contraposición con la novela, donde se podría considerar estático sobre todo a nivel espacial, pues Tristana no abandona nunca la casa de don Lope exceptuando las visitas al estudio de Horacio, visitas que tendrán un fin inminente y que no consiguen dilatarse demasiado en el tiempo.

El carácter de Tristana se presenta más accesible al lector que al espectador, pues Galdós lleva a cabo un lento análisis psicológico introspectivo, típico de la novela decimonónica, en donde da cuenta de los deseos y ambiciones de la joven, así como de su «despertar» intelectual (Galdós, 2001: 129), de su enamoramiento apasionado y de la evolución de sus pensamientos conforme a su transformación. Buñuel, por el contrario, «muestra la psicología de los personajes mediante la adecuada selección de unos pocos detalles significatitos» (Amorós, 2013: 324), entre los que se destaca que Tristana elija entre dos cosas iguales (dos columnas, dos garbanzos, dos calles), una actividad que puede parecer un juego infantil, y entonces se asociaría a su inocencia, o tal vez se interprete como una elección absurda e insignificante, lo que denotaría la parte de Tristana menos pragmática, o incluso la incapacidad de decidir sobre su propia vida. También hay quien lo relaciona con una «obsesión por poder controlarlo todo, por tener control sobre su destino pudiendo de esta manera satisfacer todas sus pulsiones» (Hernández y Velasco, 2015: 582), aunque esta lectura no resulte demasiado satisfactoria, pues Tristana no muestra en ningún momento ser controladora.

Otro aspecto fenomenológico que constituye la parte central de la novela pero que Buñuel omite, es la correspondencia epistolar. En ella, el lector asiste a un lenguaje muy sobrecargado y puede evaluar la intensidad 
del enamoramiento de Tristana así como los infantilismos en los que cae y la creación del lenguaje privado de los amantes. Estas cartas son también un buen medidor del idealismo casi religioso que paulatinamente va invadiendo a Tristana, identificando a Horacio con una especie de deidad, y serán también la muestra del desvanecimiento de la pasión. En definitiva, las cartas muestran en primera persona la parte más vulnerable de la joven, y al eliminarlas del filme, Buñuel fomenta una visión de Tristana más fría y cruel, en consonancia con la transformación que lleva a cabo de la protagonista.

Por otro lado, mientras que se entiende por carácter el modo de ser y por gesto el modo de hacer, conformando al personaje como unidad de acción (Cassetti, 1991: 178), resulta muy contradictoria la Tristana literaria, quien se presenta como una idealista desaforada, deseosa por conseguir ser «libre y honrada» (Galdós, 2001: 133, 198, 226, 230, 240), que defiende la independencia económica como medio para alcanzar la emancipación femenina y rechaza el matrimonio por considerarlo una atadura que impide la realización de la libertad. Pero, al mismo tiempo, no lleva a cabo ningún acto que le acerque a esos objetivos, y los que realiza (como rechazar las insistentes ofertas de matrimonio de Horacio) la alejan de la ansiada emancipación de la casa de don Lope, identificada como una prisión, pues se la nombra en más de una ocasión como «cautiva» (Galdós, 2001: 167). Igual de contradictoria aparece la de Buñuel, pues aun consiguiendo escapar de su cautiverio, representado en esta ocasión a través de un sueño de Tristana en el que Saturno juega con un pájaro enjaulado (Hernández y Velasco, 2015: 582), yéndose con Horacio, en el momento en el que enferma, regresa voluntariamente a esa misma jaula.

De esta forma, el receptor advierte que Tristana no es, bajo ningún concepto, un personaje plano y que, de acuerdo con su carácter, habrá una transformación tanto psíquica como física que desemboque, de nuevo, en un cambio de identidad.

El soporte de esta identidad es, según Cassetti, la «identidad física» (1991: 178). A pesar de que la relación entre carácter y físico sea más evidente en don Lope, pues en el filme aparece de manera explícita la relación entre el acicalamiento que se autorrealiza y la valentía que adquiere entonces para ser hipócrita y despótico; cabe destacar que a la Tristana literaria siempre se la compara con objetos materiales: «si toda ella parecía de papel»(Galdós, 2001:109), constituyéndola como una posesión del sujeto masculino: «pues le pertenecia como una petaca, un mueble o una prenda de ropa» (Galdós, 2001: 110); y siendo así, equiparada a un bien: «vales más que cuantas joyas he perdido» (Galdós, 2001:185); «Dígase lo que se quiera [...] bien me la he ganado» (Galdós, 2001: 127). Este bien se asocia a tener honor, que, cuando se trata de una mujer, indiscutiblemente se refiere a la virginidad, lo que refuerza la idea de propiedad a partir de la adquisición: como don Lope tiene la virginidad 


\section{Laura Sánchez López}

de Tristana, automáticamente toda ella le pertenece. Se establece de esta forma la distinción entre sujeto, don Lope, «aquel que se mueve hacia el Objeto para conquistarlo (dimensión del deseo), y a la vez como aquel que [...] actúa sobre él y sobre el mundo que lo rodea (dimensión de la manipulación)» (Casetti, 1991: 184); y objeto, Tristana. Más adelante se verá cómo en el filme hay una inversión de estos papeles.

Aunque Galdós mencione la belleza de Tristana, es más explícito en la cosificación que sufre, mientras que Buñuel decide, en relación al físico, potenciar la sexualidad de la protagonista, quien será, en todo momento, objeto de deseo de Saturno. Además, el atractivo es algo que desaparece en el personaje literario: « $i$ Cuán desmejorada la pobrecita [...] Tristana no era ya ni sombra de sí misma» (Galdós, 2001: 245), algo que no sucede en el filme.

Para cerrar la cuestión de las referencias físicas y, a su vez, clausurar el primero de los tres niveles que intervienen en la caracterización del personaje, conviene retomar la comparación que se establece entre Tristana y el papel: «De papel nítido era su rostro blanco mate» (Galdós, 2001: 109), por ser esta una metonimia de la blancura de la protagonista que se asociará, en un primer momento, a la belleza y a la juventud, y, hacia el final de la novela, será un símbolo de muerte: «su fisonomía pálida» (2001: 269); «su palidez a nada puede compararse; la pasta de papel de que su lindo rosro parecía formado era ya de una diafanidad y de una blancura increíbles» (2001: 245-246). Buñuel retrata esto en su filme de dos maneras: la primera es vestir a la actriz Catherine Denueve de negro tanto en la primera escena como en la de su casamiento, pues entre otras interpretaciones simbólicas que se le puedan atribuir, un color oscuro potencia el contrastre de uno claro. La segunda tiene lugar en el icónico momento cuando Denueve se inclina para besar la estatua blanca del cardenal Tavera y «entre ambos brota el diálogo entre la dulce intesidad de la vida y la dura intensidad de la muerte» (Barreiro, 2018, s. pág.). En cualquier caso, el color blanco es un símbolo que cambiará de significación dependiendo del momento de la historia en el que el receptor se encuentre.

El segundo nivel analiza el personaje en término formales: la clase de actitudes que adopta y las acciones expresadas (Cassetti, 1991: 183); «más que los matices de su personalidad, se pondrán de relieve los géneros de gestos que asume [...] las clases de acciones que lleva a cabo» (1991: 179). Es decir, se analiza el personaje como rol. Bajo esta premisa se presenta el personaje como mezcla de alguien activo y pasivo: el activo «se sitúa como fuente directa de la acción, y que opera, por así decirlo, en primera persona» (1991: 179); el pasivo «es un personaje objeto de las iniciativas de otros, y que se presenta más como terminal de la acción que como fuente» 
(1991:179). Tristana adopta el rol de pasiva y activa intermitentemente porque, por un lado, sufre las decisiones de don Lope, como es el trasladarse a su casa, el no poder salir a la calle, e incluso llega a hacer propias las ideas liberales y progresistas que le implanta este, a pesar de que ella sea consciente de lo hipócrita que resulta su "tutor". Pero, al mismo tiempo, muestra un rol activo al desobedecer las órdenes de don Lope, al acudir al estudio de Horacio, al escribir las cartas (en la versión literaria), al abandonar la casa "paterna" y a su vez regresar a ella (en la versión fílmica). No es posible decir de manera unívoca si Tristana desempeña un rol activo y pasivo, ya que se mueve entre ellos a modo de vaivén. Sin embargo, sí es posible establecer una mayor pertenencia al rol activo en el filme, especialmente considerando la acción final, indudablemente activa; al contrario que en la novela, donde Tristana se mostrará predominantemente pasiva, sobre todo a partir de la amputación.

Igual de ambigua es la distinción entre personaje autónomo o influenciador. Tristana se presenta a sí misma como alguien autónomo, pero esto solo atañe al carácter, pues en el gesto se muestra completamente dependiente (más en la novela que en la película). Por el contrario, indudablemente influenciador es don Lope, culpable de la situación social en la que Tristana se encuentra (mujer deshonrada y, por ello, excluida de la sociedad), así como principal configurador de la mentalidad de esta (explicitado en el capítulo IV). Sin embargo, en el filme acaba teniendo un papel autónomo, tanto en su decisión de huir con Horacio como en la acción vengativa final contra don Lope, mientras que en la novela Tristana se deja hacer sin oponer ninguna resistencia.

También resulta complicado encasillar, sobre todo a la Tristana literaria, en un personaje modificador o conservador precisamente de la dificultad anterior de decidir si era autónomo o no, ya que en esta distinción la acción es determinante y no se puede decir que Tristana sea siempre agente (con una diferencia sustancial en la versión cinematográfica). Los modificadores operan activamente en la narración y actúan como motores para cambiar las situaciones, en sentido positivo (mejorador) o negativo (degradador); los conservadores cumplen la función de preservar el equilibrio o restaurar el orden amenazado (Casetti, 1991: 179-180). La de Galdós, mucho más tímida que la de Buñuel, no pasa nunca del plano de la palabra al de la acción cuando de cambiar una situación injusta se trata. Rechaza a Horacio por influencia de don Lope, pero termina casándose con el segundo, lo que en la novela supone una restauración del orden normativo, en donde la mujer es sirvienta del hombre y la unión socialmente aceptada es el matrimonio. Tristana termina entregándose a la religión y a las dotes culinarias, convirtiéndose así en un personaje conservador en todo el sentido de la palabra (retrata fielmente a la española del siglo XIX). Por el contrario, la Tristana provocativa de Buñuel es un personaje modificador, pues aun 
sometiéndose en un principio a las normas sociales impuestas y recurriendo de igual manera que la de Galdós al matrimonio, acaba modificando la situación (si es mejorador o degradador es decisión del lector).

Los problemas para identificar los roles del personaje van en coherencia con la caracterización de complejo que anteriormente se le ha concedido. Además, es un signo que aporta la apariencia de veraz, pues resultaría poco verosímil que un ser humano permaneciese inamovible en sus ideales y actitudes. De esta forma se podría justificar, como se verá más adelante, el cambio en Buñuel del rol de inocente al de vengativo, o del de sumisa a dominante, y, en el caso de Galdós, del papel de revolucionaria a conservadora.

El tercer y último de los niveles propuesto por Cassetti, el abstracto, hace referencia al personaje como actante: «los nexos estructurales y lógicos que lo relacionan con otras unidades [...] elemento válido por el lugar que ocupa en la narración y la contribución que realiza para que ésta avance» (1991: 183). En este nivel se traspasa la categoría de personaje, pues un actante es todo aquello que se convierte en «núcleos efectivos de la historia» (1991: 183). Sin profundizar en las distinciones internas que establece Cassetti, se considera que un actante fundamental es la amputación de Tristana, por tratarse de un punto de inflexión que desencadena o culmina, según se observe, el proceso de transformación de la joven y que la crítica ha interpretado de muy diversas maneras.

Tanto el narrador como el focalizador, cada uno en su campo correspondiente, obliga al lector-espectador a detener su atención en este hecho, que puede considerarse de manera aislada (la intervención quirúrgica en sí) o puede también englobarse en un proceso de transformación, como se analizará más adelante. Este actante se presenta, analiza y aborda desde muy diversas perspectivas, tanto por parte de los autores como por la de los críticos, empezando por considerar la amputación como hecho aislado; se encuentra en Galdós una descripción minuciosa de la intervención quirúrgica, que se ha asociado a la corriente naturalista típica de la época, mientras que Buñuel concentra todas esas descripciones en una única secuencia demoledora en donde aparece en primer plano Catherine Denueve tocando el piano con una sola pierna.

La amputación en sentido más metafórico se ha interpretado por la crítica, en la versión literaria, como un castigo moral, como un fracaso del idealismo o como un reflejo fiel de la sociedad decimonónica. En el presente trabajo esta acción interesa más por ser un elemento constitutivo de la identidad de Tristana y por reflejar de manera explícita su transformación psíquica. Por lo tanto, resulta pertinente rescatar el artículo de Manuel Asensi (2008) en el que interpreta la mutilación como 


\section{La interdiscursividad en la transfiguración de Tristana}

la consumación última de la pasión sexual sadomasoquista que une a don Lope con Tristana. A pesar de no compartir en su totalidad la lectura que realiza Asensi, sí cabe admitir la presencia de una relación sadomasoquista, plausible en el simple hecho de que la Tristana literaria no abandona nunca a don Lope a pesar de renegar de él y, al mismo tiempo, de defenderlo. También está explícito en conversaciones con Horacio: «Pégame, hombre, pega... rómpeme una costilla»; «coges un palito y me pegas» (Galdós, 2001: 210, 200), que se entiende como la manifestación del correlato de la relación en igualdad de condiciones. Pero, sobre todo, Galdós muestra una perversión de la estructura básica de la familia, en donde la unión de Tristana y don Lope solo será aceptada socialmente a través del matrimonio; hasta entonces, los roles familiares van variando y así se pasa de señora a sirvienta o de padre a marido.

En la Tristana cinematográfica, el sadomasoquismo es exclusivo de la relación entre esta y don Lope: en primer lugar, porque a pesar de aborrecerlo, cuando enferma regresa a él; en segundo lugar, se intuye en una conversación que tiene Tristana con su confesor:

- Confesor: Cuando verdaderamente te hizo daño lo aceptaste todo sin protestas, y precisamente ahora, cuando se porta mejor contigo... ¿por qué?, ¿qué más puedes pedir?

- Tristana: Cuanto mejor es, lo quiero menos.

El confesor le responde que ese sentimiento es irracional y que esconde algo de satánico.

Es importante el componente sadomasoquista porque de él deviene el mundo de las pasiones sexuales, así como la represión del deseo sexual, abordado en ambas obras: en la novela, de manera implícita se exponen, según Marcelo Topuzian ${ }^{1}$, las consecuencias involuntarias de tener un deseo, frente al filme, donde se abordan de manera mucho más explícita las consecuencias de reprimir los deseos sexuales. Amorós declara que Buñuel «exagera elementos y aspectos que ya estaban presentes, de modo implícito, en la novela de Galdós» (1977: 328), y este es el ejemplo más esclarecedor: potenciar las relaciones sadomasoquistas y mostrar las consecuencias de reprimir los deseos. Un ejemplo de esa represión aparece representado en la pareja burguesa que se escandaliza al ver a Tristana y Horacio dándose un beso en el espacio público: «esas cosas se hacen en casa». Las consecuencias de reprimir los deseos se hacen visibles en el sueño recurrente de Tristana en donde aparece la cabeza de don

\footnotetext{
${ }^{1}$ Clase impartida por el Doctor en Letras Marcelo Topuzian en la Universidad de Buenos Aires, el 23 de agosto de 2017 (segunda unidad de la Cátedra de Literatura Española III).
} 


\section{Laura Sánchez López}

Lope como si fuese un badajo, en la neurosis que se apodera de don Lope, en la mutilación que sufre Tristana y, evidentemente, en la venganza final, entendida entonces como consecuencia de un deseo perverso originario en la represión de un deseo sexual. Se podría decir que mientras que Galdós decide mostrar los efectos, es decir, lo que sucede cuando una anomalía tiene consecuencias en el plano social (refiriéndose a la estructura familiar y a la relación de Tristana con don Lope), Buñel opta por remontarse al origen de esas acciones.

Por otro lado, el deseo en Galdós no sobrevive a la amputación y desmejora a Tristana: «su rostro había adelgazado tanto, que muchos que en sus buenos tiempos la trataron apenas la conocían ya [...]. Representaba cuarenta años cuando apenas tenía veinticinco» (Galdós, 2001: 298). Sucede lo contrario en el filme, pues la invalidez no le arrebata el erotismo que arrastra durante toda la película: «estás muy bonita, cada día más hermosa $[\ldots]$. Tu cojera te parecerá un obstáculo, pero eres quizá más apetecible». De esta manera, «la amputación actuará como una castración simbólica, pero al contrario que en la novela, no apaga su deseo sexual, sino que lo pervierte» (Hernández y Velasco, 2015: 582).

De hecho, el fetichismo con el que Buñuel arropa a la protagonista después de la amputación se puede observar en los múltiples enfoques que hace sobre la pierna ortopédica. En una escena, adquiere una connotación marcadamente sexual: se enfoca cómo Tristana deposita su ropa interior encima de la pierna ortopédica que se encuentra en la cama, y, con ayuda de las muletas, se asoma al balcón y se muestra desnuda ante Saturno, sonriente, complacida, sabiéndose deseada. El director consigue así marcar la supervivencia de los deseos sexuales a pesar de haber sufrido una mutilación, lo que supondría dejar de pertenecer a la categoría de cuerpos hegemónicos susceptibles de ser deseados.

Una vez concluida la configuración del personaje en sus tres niveles, llegamos al proceso de transformación que realiza. A pesar de haberlo mencionado brevemente y anunciado repetidamente a medida que se analizaba la caracterización de Tristana, es relevante unificar ahora su evolución, ya que justifica la elección del cierre de ambas obras y, además, se muestra coherente con el análisis previo. Es decir, los deslizamientos que se realizan ofrecen coherencias sistémicas (Pérez Bowie, 2004: 284285) y sugieren que Buñuel se ha alejado de Galdós para adoptar otro modelo que, por una u otra razón, convenía mejor a sus propósitos.

Lo primero que se debe observar para explicar la transformación de un personaje son dos puntos de la historia: la situación de partida y la de llegada (Cassetti, 1991: 206). Así, se entiende la transformación de la Tristana de Galdós como un proceso de degradación o un movimiento 
descendente, mientras que la de Buñuel opta por lo contrario y desempeña un movimiento ascendente o de mejora.

En ambos productos artísticos, la situación de partida es similar: Tristana es una niña inocente que acaba de quedarse huérfana y a la que se le impone la presencia de un "tutor" que la acoge, en un principio, como padre. Cuando en el filme don Lope le pide un beso, ella se lo da en la mejilla a modo de afecto filial, pero al dárselo este en la boca, ella se ríe de manera infantil, lo que denota que para ella es un juego (a pesar de que acto seguido se ponga seria, que podría interpretarse como una pérdida de la inocencia, y culmina en la escena siguiente acostándose con él). Esa deshonra se acepta en ambos casos con cierta naturalidad y resignación. En este punto, ambas son sumisas, tratadas como objetos, domésticas y normativas, en tanto en cuanto la situación de la mujer es siempre de obediencia e inferioridad para con el hombre.

Sin embargo, la implantación de ideas revolucionarias por parte de don Lope, que originan en Tristana un despertar (abordado intensamente en la novela y apenas mencionado en la película), no tiene efectos idénticos. Aunque en ambas suponga un aborrecimiento de su cautivador y el consiguiente sublevamiento (salir a pasear sin permiso), solo la de Buñuel encara abiertamente a su carcelario y expresa su aversión de manera mucho más directa que la de Galdós. En este punto se empiezan a distanciar los resultados de las transformaciones.

La amputación ya antes mencionada, no solo atañe al mundo de las pulsiones, sino que también supone una serie de consecuencias en la configuración de Tristana y es un motor indiscutible de su transformación psicológica (ya que la relativa a la física ha sido anteriormente abordada con relación al ámbito del deseo). La amputación se puede interpretar como un suceso, entendido en el sentido que le otorga Cassetti: los sucesos no se controlan, el personaje se ve inmerso en ellos y solo puede afrontarlos, sufrirlos, evitarlos, etc. (1991: 188). Este suceso origina el resto de las acciones consiguientes. En primer lugar, es el principal motivo de la frustración de los deseos de las dos Tristanas. El precio a pagar por la imaginación de un orden social alternativo, igualitario y utópico es un exceso, respecto del orden social, que en el cuerpo de Tristana se materializa en la mutilación.

En la novela, supone una conversión en su contrario, pues Tristana pasa del idealismo emancipatorio, progresista, al espiritualismo religioso. El final doméstico (y, para más inri, casada con su opresor) es un fracaso de todos y cada uno de los sueños de la joven, que acepta su destino (del que nunca consigue escapar, algo también típicamente naturalista) con resignación y buscando refugio en el mundo religioso.

Cabe recordar que el narrador galdosiano daba vida y voz propia a los personajes, y que todo lo que el lector sabía de Tristana, era por ella misma (sobre todo a través de la correspondencia epistolar); en este 
sentido, es realmente significativo que a partir de su conversión (en donde se incluye la enfermedad y, por supuesto, la mutilación) desaparezca por completo la voz de Tristana, reemplazada por el narrador y otros personajes.

Galdós describe ese final con ambigüedad, ya que cierra la novela con una pregunta cuya respuesta es un indefinido «tal vez», y con cierta ironía, según la crítica, ya que después de haber elaborado con tanto esmero a un personaje completamente atípico para finales del XIX, su fracaso tiene que esconder un significado oculto, traducido en una denuncia a la situación de la mujer de la época: «¿Pudo hacer Galdós que el personaje no se acomodara, digamos, tan mansamente? Sí, pero eligió un desarrollo de los acontecimientos, un discurrir de la historia más tranquilo y acorde con los tiempos, la sociedad y el fluir normal de la vida» (Palacios Martínez, 2013: 394). Andrés Amorós también opina que detrás de ese final suspendido hay algo más: «Galdós se ha detenido, no ha querido ir más allá (en todos los sentidos de la expresión). Pero, por debajo de la suave ironía resignada, la amargura implícita en la historia se puede percibir con facilidad» (1977: 323).

De esta forma, la Tristana literaria se pliega y abandona, nunca llega a ser sujeto agente de sus acciones ni deja la condición de cautiva y se evade de la vida terrenal; a todo ello se suma la decadencia física que ya se ha mencionado. Si comienza siendo una mujer incapaz de ocupar ninguno de los roles típicos de la sociedad que la rodea, lo que le confería el distintivo de personaje singular, termina casada, beata y cocinando postres, lo que la reinserta en la sociedad bajo el canon más normativo que pudiera existir y la despoja de cualquier deseo propio. Su última metamorfosis es la aceptación resignada de sus limitaciones (Palacios Martínez, 2013: 392), por lo que Tristana lleva a cabo un trayecto descendente.

No hay punto de comparación con la Tristana de Buñuel, quien, a pesar de presentar al receptor su inicial inocencia, decide potenciar una imagen de Tristana completamente sexualizada y con indicios de mujer perversa, anticipando el final de la conversión: de la virtud y la inocencia se pasa a la maldad y perversión. Muestra de ello es, entre otras, la escena del partido de fútbol de los sordomudos en donde Tristana le ofrece a Saturno una manzana, asociada al pecado y a la pérdida de inocencia (Palacios Martínez, 2013: 396).

La transformación de la Tristana de Buñuel se vincula estrechamente con la relación que mantiene con don Lope $\mathrm{y}$, finalmente, por el intercambio de roles que se realiza con este. Al inicio, ella se muestra sumisa, llamándolo «señor»y, a pesar de mostrar rechazo, cuidándolo cuando él enferma; sin embargo, «expresa más claramente que en la novela su odio por don Lope» (Amorós, 1977: 324) con frases como: 
«ojalá me quisiera menos»; «si puediera largarme y no volver a verle nunca más en carne y hueso». Es un personaje más consciente de las cadenas que arrastra y va acumulando un resentimiento que se terminará por transformar en odio.

Las pantuflas de don Lope simbolizan la degradación de la relación entre ambos, pues si al principio esta, arrodillada ante él, lo calzaba cariñosamente, en señal de respeto y obediencia absoluta, hacia mitad de la obra aparecen las pantuflas roídas, desgastadas, y Tristana las tira a la basura. Es un acto simbólico que refleja la ruptura entre ambos.

Además, Tristana no lo toma en serio, para ella es un simple viejo que solo adopta un carácter despótico cuando se acicala: «el gallo pierde sus plumas y ya no canta [...] en cuanto se adoba se envalentona, vuelven a salir las plumas». Después de la operación incluso lo ridiculiza abiertamente, llamándolo «Lopito» (en contraste con el «Tristanita» del inicio), o, en la noche de bodas, le dice: «hay que ver, que tengas a tu edad todavía esas ilusiones me parece increíble».

Algo que se le ha criticado a este personaje es que, en teoría, haya dejado de lado la denuncia inicial de la situación de la mujer española a finales del XIX. Sí es cierto que aparece más reiteradamente en la novela, pero no hay que olvidar que la de Buñuel consigue, en parte, la emancipación soñada por la de Galdós y que, más que decir que quiere ser libre, lo muestra. Otra posible lectura es que el director decidiese «centrarse en el tema de la mujer juguete de un destino y de unas circunstancias adversas, progresivamente endurecida y cruel» (Amorós, 1977: 324), realizando así un estudio «profundo y terrible [...] de las relaciones humanas, de la frustración vital» (1977: 328), lo que sería coherente teniendo en cuenta el devenir del personaje.

Volviendo a la relación de don Lope y Tristana, la mutilación supone el progresivo endurecimiento del carácter de ella, que directamente evita toda clase de contacto físico con don Lope, precisamente cuando él, ya muy deteriorado, se muestra especialmente atento y cariñoso con ella: por fin (pero demasiado tarde) aparece la figura del padre. He aquí la inversión de los roles: Tristana pasa de seducida a seductora, de sumisa a dominante, y don Lope es un sirviente que le compra dulces y obedece a sus órdenes. Buñuel representa esta inversión a través de elementos visuales como el bastón: si antes era don Lope el portador, ahora lo es Tristana y lo usa tanto para andar como para dar golpes en el suelo, enfatizando sus órdenes. El bastón en don Lope ya no es símbolo de poder, sino de vejez. También esta toma del control y de superioridad se traspasa a la pantalla a través de elementos sonoros: en las últimas escenas, completamente convertido, don Lope toma chocolate con tres curas mientras suena de fondo el sonido grave e incesante de las muletas de Tristana (Hernández y Velasco, 2015: 583). 


\section{Laura Sánchez López}

La conversión de Tristana deriva hacia la violencia, y la decisión de llevar a cabo una acción vengativa es lo que más la diferencia de la de Galdós. Buñuel cierra la novela sin ambigüedades ni ironías, «lleva el conflicto a sus últimas y más agrias consecuencias» (Amorós, 1977: 323) y Tristana «hace realidad su sueño recurrente y premonitorio, ese sueño que la liberará definitivamente» (Palacios Martínez, 2013: 397). Que el final sea más claro no lo exime de misterio: la incógnita es por qué Tristana regresa donde se encuentra don Lope. Si se retoma la cuestión de los deseos, nuestra lectura del final del filme es que, al sobrevivir el deseo a la mutilación, este será el motor para que se inviertan los roles: Tristana aparece integrada en el orden social (debido al casamiento), pero reserva sus transgresiones para la vida privada. La liberación, entonces, queda restringida al ámbito privado. La realización de la venganza se asociaría, por lo tanto, a la consecuencia de un deseo perverso originario de la represión de un deseo sexual ${ }^{2}$.

En definitiva, lo que sintetiza la transformación de la recreación cinematográfica es, al contrario que en la novela, un movimiento ascendente y, en el caso de Tristana, de mejora. Esta acción, que en un primer momento se puede entender como violenta y excesiva, representa un empoderamiento de la mujer que ha sufrido en silencio las injusticias del tirano.

\section{El PORQUÉ DEL CAMBIO DE LA VISIÓN DE LA MUJER}

No es la primera vez que Buñuel recrea una obra galdosiana y no se debe olvidar que de las treinta y dos películas que componen su filmografía, dieciocho son adaptaciones (Hernández y Velasco, 2015: 573), lo que no ha impedido que el cineasta conjugue bien su personalidad como autor con el diálogo que ha mantenido con estos textos literarios. En Tristana realiza una lectura e interpretación del texto de Galdós y le da una respuesta al mismo, incluyendo su particular visión del mundo y exponiendo «sus obsesiones y recuerdos de un modo perturbador» (Hernández y Velasco, 2015: 572). De esta manera, en el filme están presentes los temas por antonomasia de Luis Buñuel, como son el sexo, la muerte, el fetichismo, la relación arquetípica del viejo y la niña o el deseo (2015: 586).

A pesar de que el realizador admitió que quien captura su atención de la obra no es Tristana, sino don Lope, por tratarse de una especie de alter ego del propio cineasta, no se queda atrás el tratamiento que recibe el personaje femenino. A través de él realiza, al mismo tiempo, la

\footnotetext{
${ }^{2}$ Lectura realizada por Marcelo Topuzian (consúltese nota 1).
} 
actualización de la Tristana de Galdós, pero al mostrar también las similitudes con esta «nos está diciendo claramente que la historia de Tristana, tal como él la ve, no es una historia del siglo pasado, sino algo mucho más próximo, que brota de la España tradicional y está en las raíces mismas del presente» (Amorós, 1977: 322).

Lejos de los motivos personales que tuviera Buñuel para conformar la identidad de Tristana, es indispensable dirigir la mirada hacia los márgenes, hacia el contexto:

El personaje responde, además, a las exigencias de otros códigos, principalmente los que encarnan los sistemas de valores de cada época histórico-cultural en lo más diversos ámbitos [...]. En este sentido sí puede decirse que todo personaje es portador de los estigmas de su tiempo (Garrido Domínguez, 1996: 103).

Así, aunque el contexto de producción varíe casi un siglo, Buñuel decide ambientar su Tristana entre los años 20-30, apenas 40 años después de la de Galdós, para, quizás, resaltar y denunciar la situación de la mujer española del siglo XX, situación que se asemejaba más a la que había en Europa en el siglo XIX, pues la mujer, aunque ya tenía acceso a la educación y derecho al voto, hacia 1930 tenía que abandonar la vida pública del trabajo asalariado en cuanto fuesen madres, para dedicarse en su plenitud a la vida doméstica, y, además, «solo existía un modelo femenino aceptado socialmente [...] estaba justificada su permanente tutela por un varón [...] lo adecuado era estar casada y ser madre, el único objetivo vital»; «las mujeres tenían obligaciones de carácter. Todas tenían que ser obedientes, abnegadas, humildes y cariñosas [...] y una única virtud era inexcusable: tener probada honradez» (Varela, 2008, s. pág.).

Esta retrógrada situación, alimentada por la dictadura franquista (como puede observarse, las definiciones de la España del XX son aplicables a la sociedad de Galdós de 1892), pudieron ser un motivo que impulsase a Buñuel a reflejar de manera crítica cómo la sociedad reprime y castra a todo sujeto que no siga el modelo hegemónico creado por las autoridades.

Así, Buñuel configura a un personaje sexualizado en un mundo extremadamente religioso en donde toda pulsión es pecado, pero al mismo tiempo muestra las hipocresías internas de ese pensamiento burgués, el cual adopta una actitud irreprochable en el espacio público, convirtiéndose en un déspota contra los que considera inferiores en el espacio privado de la casa. Además, la mujer reúne todas las herramientas intelectuales adquiridas por don Lope y, fingiendo una llamada, consigue alcanzar su libertad. Deformada y deseada, logra vengarse de un sistema que la repudia hasta el momento en el que se casa (vestida de luto, como si de un funeral se tratase) y alcanza un final victorioso porque la obediente, 
abnegada y humilde Tristana, supera a la tímida y resignada de Galdós para afianzarse en la vida terrenal con más voz que nunca.

\section{BibliografíA CITADA}

Albaladejo, Tomás (2008), «Poética, Literatura Comparada y análisis interdiscursivo», Acta Poética, 29/2, págs. 245-275.

Amorós, Andrés (1977), «Tristana, de Galdós a Buñuel», en AA.VV., Actas del I Congreso Internacional de Estudios Galdosianos, Las Palmas de Gran Canaria, Cabildo Insular, págs. 319-329.

ASENSI, Manuel (2008), «Unsex me here: Tristana y la pasión», Scriptura, 19/20, págs. 111-140.

Barreiro, Xosé Luis (2018), «Catherine Denueve y el cardenal Tavera», $\mathrm{La} V \mathrm{Voz}$ de Galicia [En línea:

https://www.lavozdegalicia.es/noticia/opinion/2018/01/13/cather ine-deneuve-cardenal-tavera/0003_201801G13P12993.htm].

PÉrEZ BowIE, José Antonio (2004), «La adaptación cinematográfica a la luz de algunas aportaciones teóricas recientes», Signa, 13, págs. 277300 .

CASetTi, Francesco (1991), Cómo analizar un film, Barcelona, Paidós.

DOLEŽEL, Lubomír (1990), «La transducción literaria», en Historia breve de la poética, Madrid, Síntesis, págs. 229-237.

Galdós, Benito [Pérez] (2001), Tristana, Madrid, Akal.

Garrido DomíngueZ, Antonio (1996), «El personaje», en El texto narrativo, Madrid, Síntesis, págs. 67-102.

Hernández, Esmeralda y Ana María Velasco (2015), «Tristana: entre Galdós y Buñuel. Un análisis textual de la adaptación cinematográfica», en E. Camarero y M. Marcos (eds.), III Congreso internacional. Historia, arte y literatura en el cine español y portugués. Hibridaciones, transformaciones y nuevos espacios narrativos, Salamanca, Hergar Ediciones Antema, págs. 572-587.

Palacios Martínez, Feliciana M. (2013), «Tristana. Galdós y Buñuel, del feminismo a la violencia», en M. P. Celma, M. J. Gómez del Castillo y S. Heikel (eds.), Actas del XLVIII Congreso Internacional de la AEPE. EI español en la era digital, Universidad de Zaragoza, págs. 391-397.

VArela, Nuria (2008), Feminismo para principiantes, Barcelona, Ediciones B [edición en formato electrónico].

Fecha de recepción: 03/07/2019.

Fecha de aceptación: 29/07/2019. 